https:/jurnal.unigal.ac.id/index.php/jall/index

ISSN: 2598-8530

September 2018, Vol. 2 No. 2

English Education Program

Faculty of Teacher Training and Education

Galuh University

\begin{tabular}{|ccc|}
\hline Received: & Accepted: & Published: \\
\hline July 2018 & August 2018 & September 2018 \\
\hline
\end{tabular}

\title{
A TRANSITIVITY ANALYSIS OF MALE AND FEMALE STUDENTS' FINAL DRAFT OF CRITICAL RESPONSES PARAGRAPH TO LITERATURE
}

\author{
Nia Siti Hadiyati \\ niyahadiyati198@gmail.com \\ Iskhak Said \\ iskhak.said@yahoo.com \\ Bambang Ruby Sugiarto \\ bambangrubys@gmail.com
}

Galuh University, Ciamis, West Java Indonesia

\begin{abstract}
This study aims at investigating the realization of transitivity particularly process, participant and circumstance types realized in male and female students' final draft of critical response paragraph to literature. A descriptive qualitative method was employed in analyzing and interpreting the whole data. Furthermore, eight students' final draft of critical response paragraph to literature which were categorized into male and female students' critical response paragraph. The findings showed that (1) most of the male and female students were able to realize the transitivity in which the transitivity was realized through the clauses that construct meaning of every single text. (2) Most dominant process realized in eight texts were material process, while actor and goal became the most dominant participants realized and circumstance of location became the most dominant circumstance realized in every single text. However, male students were tend to use the material process in their texts. This study concludes that even though the text were categorized into male and female students' text, most of the text had realized correctly transitivity while both male and female students' final draft of critical response paragraph to literature, material process dominantly emerged in the text.
\end{abstract}

Keywords: transitivity, critical response, literature 


\section{INTRODUCTION}

Numerous theories have been successful in accounting for aspect of language. A language is viewed as a resource for making meaning in 'Systemic Functional Linguistic theory" (Halliday and Mattheissen, 2014, p. 23). One of the most substantial theory is Halliday's SFL that has attracted the most attention and has been frequently employed in the Literature on linguistics and applied linguistics. Systemic Functional Linguistic develops in its own grammatical form namely 'Systemic Functional Grammar'. Furthermore, Eggins (2004, p. 21) states that SFL is not only a model of grammar but it is also contributing the way to represent an approach in analyzing the discourse. In other words, SFL has widely given a very significant influence on discourse analysis (Sugiarto, B.R., 2015). According to SFL theory, a text is generated in two ways. Those are spoken and written text. To analyze a written text, discourse analysis (DA) can be used as an approach in which it is still part of SFL. This statement is also in line with Eggins (2004, p. 24) in order to analyze text, discourse can be used and it is known as Discourse Analysis.

Dealing with discourse analysis, it can draw a conclusion that discourse analysis can be used as an approach which functions to analyze a text both spoken and written texts. Meanwhile, DA itself is widely known as a part of systemic functional linguistic (SFL) which was designed by Halliday not only as a model of grammar, but also as the way of representing a text meaning.In the context of language, SFG focuses on three meanings namely ideational meaning, interpersonal meaning, and textual meaning. In this research, the writer focuses on the 'ideational meaning'. Furthermore, Eggins (2004, p. 206) stated that the 'ideational meaning' consist of two parts such as 'experimental' and 'logical meaning'. It is realized through the 'transitivity system'.

Transitivity system is used as a tool for analyzing male and female students' final draft of critical responses paragraph to literature in Galuh University. Critical response is a literary critical theory. It is promoted and 
developed by a variety of literary theorists and critics. Depending on the person advancing the concept, the theory may take on any number of nuanced meanings (Davi, 2017). Furthermore, every student has different style when they make a critical response to literature. According to Klarer (2004, p. 1), in most cases, literature is referred to as the entirety of written expression, with the restriction that not every written document can be categorized as literature in the more exact sense of the word.

\section{The Nature of Transitivity system}

In traditional grammar, transitivity was developed as the concept of transitive or intransitive verb (Halliday, 1976, p. 159) whether the verb takes an object or not, but in SFL it functions to link grammar to the meta-functions. Process refers to a semantic verb (doing, happening, feeling, sensing, saying, behaving, and existing) and anything that it expresses like event, relation, physical, mental or emotional state when sorted in the semantic system of the clause is classified into material, relational, mental, verbal, behavioral, and existential processes. (Halliday, 1976, p. 159). The system of transitivity provides the lexicogramatical resources for construing a quantum change in the flow of events as a figure - as a configuration of elements centered on a process. Besides, Thomson (2004, p. 88-89) states that transitivity refers to a system for describing the whole clause, rather that just the verb and its object.

Dealing with the elaboration above, the writer concluded that the transitivity system is a system that provides the lexicogrammatical resources. Transitivity interprets events that occur based on the process. Besides, transitivity system describe the meaning of whole clause. Furthermore, the writer uses transitivity system as a tool to analyze male and female students' final draft of critical response in the form of paragraph.

\section{The Nature of Critical Response}

Davi (2017) indicates the critical response is a literary critical theory. It is promoted and developed by a variety of literary theorists and critics. Depending 
on the person advancing the concept, the theory may take on any number of nuanced meanings. Generally speaking however, critical response suggests that a text gains meaning by the purposeful act of a reader's reading and interpreting it. The relationship between reader and text is highly valued; text does not exist without a reader.

\section{The Nature of Gender}

Gender has become the centre of attention in today linguistics research which differentiates male and female in acquiring a language. According to Holmes and Meyerhoff (2003, p.13), "Women and men do not generally choose linguistic options for the purpose of creating masculine or feminine identities; instead, they draw upon gendered linguistic strategies to perform pragmatic and interactional functions of language and, thus, constitute roles in a gendered way. It is the manner in which people constitute their identities when acting within a social role that is linked with gender." The statement means that there is differentiation between male and female in creating their abilities to show their strategies in acquiring a language.

It is also added by Gallardo (2006) that the analysis of the transitivity system investigated the instances of the material, mental and relational processes in an attempt to suggest who has more power of doing things, and how this power is accomplished and realized through the study of the processes focused. He also revealed that the difference between male and female in transitivity is in the use of material process which the male character is the doer of more practical actions than the female. It is also realized through the mental processes that the female is moved by her emotions. The study of the material and mental processes suggests that the male acts more while the female perceives more.

\section{The Nature of Literature}

Wellek and Warren (1963, p. 22) states that "the term literature seems best if we limit it to the art of literature, that is, to imaginative literature. Literature is also produced by imagination of the author. Literature is not just a document of 
facts, it is not just the collection of real events though it may happen in the real life. Literature can create its own world as a product of the unlimited imagination"

According to Klarer (2004, p.1), in most cases, literature is referred to as the entirety of written expression, with the restriction that not every written document can be categorized as literature in the more exact sense of the word. The definitions, therefore, usually include additional adjectives such as "aesthetic" or "artistic" to distinguish literary works from texts of everyday use such as telephone books, newspapers, legal documents, and scholarly writings. Etymologically, the Latin word "litteratura" is derived from "littera" (letter), which is the smallest element of alphabetical writing. The word text is related to "textile" and can be translated as "fabric": just as single threads form a fabric, so words and sentences form a meaningful and coherent text. The origins of the two central terms are, therefore, not of great help in defining literature or text. It is more enlightening to look at literature or text as cultural and Historical phenomena and to investigate the conditions of their production and reception. Underlying literary production is certainly the human wish to leave behind a trace of oneself through creative expression, which will exist detached from the individual and, therefore, outlast its creator. The earliest manifestations of this creative wish are prehistoric paintings in caves, which hold "encoded" information in the form of visual signs. This visual component inevitably remains closely connected to literature throughout its various historical and social manifestations.

\section{METHOD}

This study applied a qualitative method particularly descriptive qualitative as the method. To investigate the quality of relationships, activities, situations, or even materials, qualitative research can be applied (Fraenkel, Wallen, \& Hyun, 2012, p.426). Furthermore, the data of this study were critical responses written by the fourth grade students in English department of Galuh University in which the text were analysed and interpreted by using functional grammar theory. Therefore, to analyse the data for description of the text analysis and interpreting the larger 
meaning of the findings, qualitative descriptive study can be employed (Creswell, 2012, p. 16). Thus, qualitative descriptive research was applied in this study in order to explore and interpret the meaning, and to get a rich data in exploring the central phenomenon. Besides, discourse analysis is part of SFL that highlighted by Eggins (1994) in the preceding paragraph. Discourse analysis in this study was done by following principle of the text and the context found in the study of systemic functional grammar.

\section{Participant and Research Site}

Fraenkel and Wallen (1932, p. 90) state that population is the larger group to which one hopes to apply the result. This research uses all the fourth grade students of English Department in Galuh University.

Sample in a research study is the group on which information is obtained (Fraenkel and Wallen, 1932, p. 90). In this study, the researcher investigated 8 students which consist of 4 male students and 4 female EFL students.

Purposive sampling : Purposive sampling in this case increased in-depth understanding by selecting information rich experiences from participants who have experienced and lived disaster relief (Patton, 2002). The purposive sampling technique, also called judgment sampling, is the deliberate choice of an information due to the qualities the informant possesses. It is a nonrandom technique that does not need underlying theories or a set number of informants. The writer chooses purposive sampling because purposive sampling enable in initial understanding of the situation, and to identify and differentiate the needs of one or more relevant groups. The writer chooses sample that consist of four male and four female fourth grade students in Galuh University because they have good experience in reading and writing reader response to short story in the literature class.

\section{Data Collection}

To Collect the data, the writer uses Systemic Functional Grammar as the instrument to collect the data. After that, the writer analyzed the male and female students' final draft of critical responses to literature in the literary criticism 
subject by using transitivity system. Furthermore, the data were obtained from the eight fourth grade students in English Department of Galuh University.

\section{Data Analysis}

First, the researcher collected the data from the third grade students of English Department in Galuh University. The researcher analyzes the male and female students' final draft of critical responses paragraph to literature. After that the researcher comprehends the theory that is Halliday theory and the researcher classifys and analyzes it. Moreover, there were several steps to analyze the data. They were segmenting the text of critical response into clauses, analyzing clauses by using transitivity system, then categorizing and highlighting all of the processes, participants and circumstances into table. Finally, the researcher identifys the characteristic of male and female students according to the process used

\section{FINDINGS AND DISCUSSION}

Regarding the finding of the study, transitivity system had been realized particularly in processes, participants, and circumstances. In addition, the most dominant processes realized from text one up to eight were material process. However, from eight texts that had been analyzed, there were three texts of male and three texts of female students which emerged material process and only one text of male and one text of female student which emerged mental process. Furthermore, the most dominant participants emerged from eight texts were actor and goal in which all of the participants were a pair of material.

Furthermore, the most dominant circumstances realized from the text male 1 up to text female 4 were circumstance of location. According to Butt et al. (2000, pp. 65-70), circumstances are realized in adverbial or nominal group in which the use of circumstances are labeled to help the reader to understand the purpose of a text. There are 12 categorization of circumstances in which they cover the circumstances of extent, location, contingency, cause, accompaniment, matter, role, manner, means, quality, comparison and angle. However, the most dominant 
circumstance emerged in eight male and female students' final draft of critical response paragraph to literature was circumstance of location in which the use of circumstance of location was referred to detail explanation of participants realized from every single text. Thus, all of most dominant processed, participants and circumstances realized from text one up to eight were linked one to another.

Based on the findings, material process became the most dominant processes involved in eight selected text. Concerning the relation to he first previous study which was undertaken by Gallardo (2006). He investigated the research entitled: "Analysis of a Literary Work Using Systemic-Functional Grammar: Why can't Women Talk like a Man: An investigation of Gender in The Play Pygmalion by Bernard Shaw". The study aimed to examine the language used by the main male and female characters in the play 'Pygmalion' by applying the lexicogrammatical category of transitivity, which is part of English linguist (systemic-functional grammar). The investigation is based on the play which has been considered one about social class may also be classified as one about gender. As for the present study, the focus was specifically on the one of process of transitivity. The analysis itself was male and female fourth-year students' critical response paragraph to literature composed by the seventh-semester students of English Education Program in Galuh University Ciamis.

Regarding the findings above, it meant that this study was not in harmony with the study. Both studies were focused on the differences of male and female language choice, but the difference was the sample who composed their writings and the tool to analyse the writing product which was in this study the writer specially focus on one of the process, participant, and circumstance in transitivity.

The second previous study which was conducted by Ezzina (2015), material process was dominantly found in the finding. The use of material process in Ezzina's finding was to indicate main character of "The Crying Lot of 49" (Oedipa) had done some action. Hence, Oedipa herself was also becoming the actor or it was also called as participant of material process. This finding was in harmony with this study. The material process was being the most dominant 
process, while the actor and goal became the most dominant participants emerged. Hence, the circumstance of location also became the most dominant circumstance emerged in the texts.

Regarding the third previous study which was conducted by Zhang (2017), the main findings show that material processes, relational process and mental processes are relatively dominate in both candidates' speeches; while compared with Hillary, Trump tends to use more existential processes. In political discourse, the speakers measure their words with special caution to interact with people, to expresses their attitudes and judgments, and to influence the viewpoints and behavior of the audience, which is mainly the realization of the interpersonal function. In contrast with this study, only the material process was dominantly realized in most of the analyzed texts, while actor and goal became the most dominant participants. Hence the circumstance of location became the most dominant circumstance realized in the texts. Circumstance of location referred to every adverbial groups such as place and time explained in every texts.

Regarding the findings above, it meant that this study was not in harmony with the study conducted by Zhang (2017) in which the each of the studies showed different findings. This study only emerged material process as the most dominant process both in male and female students' texts, while Zhang (2015) also emerged the relational and mental processes besides the material process relatively dominate in both candidates' speeches.

Based on the last previous study which was conducted by Iskhak (2015) entitled "The Application of Reader-response Theory in Enhancing Student Teachers' Affective and Linguistic Growth: A Classroom Action Research in EFL Teacher Education in Indonesia”. It showed that there were some improvements on students' boldness and self-confidence in expressing ideas, involvement in classroom activities, and linguistic growth such as writing skill by applying the reader response theory. However, he emphasizes on the aesthetic response while 
the this focus on the critical response. Therefore, this study was not in harmony with Iskhak (2015).

\section{CONCLUSIONS}

Based on the findings, the finding of first research question can be generally concluded that the transitivity was realized through clauses which constructed the meaning in every single text of critical response paragraph. Moreover, the clause conveyed the system of transitivity that consisted of process, participant and circumstance. This findings were also in line with the theory mentioned by Eggins (2004, p.206). She stated that experiential meaning is expressed through the system of transitivity particularly in process, participants and circumstances type.Meanwhile, the finding of second research question can be concluded that all of the critical response paragraphs generally used material and mental process as the most dominant process both in male and female critical response paragraph. Hence, the most dominant participants realized in eight students' final draft of critical response paragraph to literature were senser, phenomenon, actor and goal. In addition, the circumstance of location became the most dominant circumstance realized in eight students' final draft of critical paragraph to literature.

This study recommends the next researcher who would conduct this kind of study to investigate various text by using systemic functional grammar particularly transitivity. It is hoped that through different method and different kinds of texts, the researcher will be able to enrich the data and the findings, and also be able to develop the theory of SFL particularly experiential meaning. Furthermore, this study is also hoped to give advantages for English teaching and learning process especially in Literature class.

\section{REFERENCES}

Butt, D., R. Fahey, S. Feez, S. Spinks, C. Yallop. (2006) Using functional grammar: An explorer's guide, (2nd Edition), Sydney: Macquarie University. 
Cresswell, J.W. (2012). Educational research : Planning, conducting, and evaluating quantitative and qualitative research $4^{\text {th }}$ Ed. Boston: Pearson Education, Inc.

Davi, R. (2017). The role of reader in reader response theory. International Journal of English Language, Literature and Translation Studies (IJELR), 4(3), 417-422.

Eggins, Suzanne (1994). An introduction to systemic functional linguistics. London : Pinter Publisher.

Eggins, S. (2004) An introduction to systemic functional linguistics (2nd Edition), London, New York: Continuum.

Ezzina, R. (2015). Transitivity analysis of "The crying lot of 49" by Thomas Pynchon, International Journal of Humanities and Cultural Studies, 2(3), 283-292

Fraenkel, J.R., \& Wallen, N., E. (1932). How to design and evaluate research in education, New York : McGraw-Hill.

Fraenkel, J.R., Wallen, N. E., and Hyun, H. H. (2012). How to design and evaluate research in education $8^{\text {th }}$ Ed. New York : McGraw-Hill Companies Inc.

Gallardo, B.C. (2006). Analysis of a Literary Work Using Systemic Functional Grammar. International Systemic Functional Congress, 33, 735-762.

Halliday, M. A. (1976). The form of a functional grammar, in Kress, G. (ed.):725.

Halliday, M.A.K., \& Mattheissen, C. M. I. M. (2014). An introduction to functional grammar $\left(4^{\text {th }} \mathrm{Ed}\right)$. London : Hodder Arnold.

Holmes, J., \& Meyerhoff. (2003). The handbook of language and gender. Malden, MA : Blackwell.

Iskhak. (2015). The application of reader-response theory in enhancing student teachers' affective and linguistic growth: A classroom action research in EFL teacher education in Indonesia, The Application of Reader-response Theory. 45 (2), 43-55.

Klarer, M. (2004). An introduction to literary study ( $2^{\text {nd }}$ edition). London : Routledge.

Patton, M. (2002). Qualitative research and evaluation method ( $3^{\text {rd }}$ Ed.) Thousand Oaks, CA : Sage. 
Sugiarto, B.R., Sofwan, A., \& Sutopo, D. (2015). Mood Realization of The Learning Activities in The Grade VII English Textbook Published By The Ministry of Education and Culture. English Education Journal, 5(1).

Thompson, G. (2004) Introducting functional grammar (2nd Edition), London: Hodder Education.

Wellek, Rene \& Austin Waren. (1963). Theory of literature. New York : Harcout, Brace and Company.

Zhang, Y. (2017). Transitivity analysis of Hillary Clinton's and Donald Trump's first television debate. International Journal of Applied Linguistics \& English Literature. 6, 65-72. 